\title{
Aboveground biomass in reforestation with native species established by means of Taungya agroforestry system ${ }^{1}$
}

\author{
Antonio Vicente Moscogliato ${ }^{2,4}$ and José Marcelo Domingues Torezan ${ }^{3}$
}

Received: 26.09.2016; accepted: 1.03.2017

\begin{abstract}
Aboveground biomass in reforestation with native species established by means of Taungya agroforestry system). The mitigation of $\mathrm{CO}_{2}$ emission through high-productivity systems associated with restoration of degraded sites have been increasingly common, highlighting the importance of estimates of the amount and distribution of plant biomass in different ecosystems and under different management systems. The aim of this study was to investigate the influence of planting and soil characteristics and the type of management performed over the aboveground biomass accumulation in two reforestation projects with native species, implanted through Taungya agroforestry system. The differences in aboveground biomass accumulation were probably influenced by agroforestry management, since these variations showed to be independent of age (considered within the age range in this study), the spacing, the species composition, and soil fertility. The values of aboveground biomass are similar to those reported in the literature for other reforestation projects with native species of similar ages.
\end{abstract}

Keywords: Brazil legal forest reserves, carbon sequestration, ecological restoration

RESUMO - (Biomassa aérea em reflorestamentos com espécies nativas em sistema agroflorestal Taungya). Mitigar a emissão de $\mathrm{CO}_{2}$ por meio da implantação de sistemas com alta produtividade primária, especialmente em consórcio com a recuperação de áreas degradadas, tem se tornado prática comum, realçando, assim, a importância de estimar a quantidade e a distribuição da biomassa em diferentes ecossistemas e sob diferentes sistemas de manejo. O objetivo deste estudo foi verificar a influência de características do plantio e do solo e do tipo de manejo realizado sobre a biomassa aérea em dois reflorestamentos com espécies nativas, implantados por meio do sistema agroflorestal Taungya. As diferenças no acúmulo de biomassa aérea foram provavelmente influenciadas pelo manejo agroflorestal, uma vez que essas variações mostraram ser independentes da idade (dentro do intervalo considerado), do espaçamento, da composição de espécies e da fertilidade do solo. Os valores de biomassa são similares aos reportados na literatura para outros reflorestamentos com espécies nativas e de idades semelhantes.

Palavras-chave: recuperação de áreas degradadas, reserva legal, sequestro de carbono

\section{Introduction}

Biomass is any biological matter, alive or dead, from animal or vegetal origin and the term forest biomass usually refers to all existing biomass in a forest or just the arboreal fraction (Sanquetta $\&$ Balbinot 2004). Biomass is one of the most important aspects of the ecosystem structure, because it expresses the potential of energy and nutrient accumulation by the biota when interacting with environmental factors (Burger \& Delitti 1999). Each year, tons of carbon dioxide $\left(\mathrm{CO}_{2}\right)$ are converted in biomass through carbon reduction reactions associated to photosynthesis made by plants that use solar energy to oxidize water and then liberate oxygen (Taiz \& Zeiger 2002).

The carbon stock in forests is estimated by the quantification of different components, such as alive aboveground biomass (composed mainly by trees and by other forms of plant and animal life), dead aboveground biomass, composed by litter and fallen logs, and the underground biomass, composed by roots, soil microbiota and soil organic matter (Silveira et al. 2008). The arboreal biomass is frequently estimated by the indirect method, in which the

1. Parte da Dissertação de Mestrado do primeiro Autor

2. Departamento de Água e Esgoto de Bauru, Rua Padre João 11-25, Vila Santa Tereza, 17012-020 Bauru, SP, Brasil

3. Universidade Estadual de Londrina, Centro de Ciências Biológicas, Departamento de Biologia Animal e Vegetal, Rodovia Celso Garcia Cid, km 380, Caixa Postal 10011, 86057-970 Londrina, PR, Brasil

4. Autor para correspondência: avmoscogliato@yahoo.com.br 
measures of stem diameter and the height of the tree are used in regressions to estimate the biomass, thus being not destructive (Somogy et al. 2007, Silveira et al. 2008). Nowadays the demand for mitigating gas emissions lead to an increasing of initiatives of biomass quantification, in different models of tree plantations in different environments, which generated a discussion about the efficiency of those strategies (Melo \& Durigan 2006).

Agroforestry Systems (AFS) are based on the premise that land use systems that are more complex than monocultures will result in a higher efficiency in energy and nutrient capture and utilization and in more stability, thanks to the increased structural and functional diversity (Nair et al. 2009). The AFSs are viable alternatives for rural lands, needing however further research to define best management practices to enhance agroforestry production, while promoting the desired environmental and economic gains (Froufe et al. 2011).

When restoring degraded areas using native species plantations, the use of AFSs as a transition phase increases the benefit/cost relationship of restoration, helping human subsistence, reducing initial costs and increasing the time under management of the restoration sites (Vieira et al. 2009). Apart from promoting diversification on income sources and increasing food safety, the AFSs can contribute to workforce fixation and to collective organization of small farmers (Rodrigues et al. 2008).

The effect of different management systems has been little explored by literature on biomass accumulation in reforestations (Jose 2009). Management, in this context, can be defined as the set of actions that are necessary to sort production factors and to control their productivity and efficiency, achieving the expected goals (Higuchi 1994). In AFSs, the establishment, the conduction and the harvesting of agricultural species are integrated parts of management and aim to accomplish socioeconomic, cultural and environmental demands (Nair 2012).

In areas designated to ecological restoration, under legal restrictions on land use or with clear forest designation, it is common the use of Taungya agroforestry system, defined as a forest plantation where agricultural crop is allowed during the initial phases of tree establishment (Chamshama et al. 1992). The agricultural practices last until the closing of forest canopy, when the system becomes a production forest or, in some cases, an area of environmental preservation (Rodrigues et al. 2007).
One of the challenges to predict the potential for biomass accumulation in AFSs is that different tree species and the different forms by which they are combined in those systems result in heterogeneity both on quantity and quality of the biomass that is produced (Nair et al 2009). Thus, carbon capture in AFSs (both above and undergound) may vary a lot, depending on the system, the composition of species, the age of trees, weed and crop plant management, among other factors.

In this study we aimed to verify the influence on aboveground biomass of the features of tree species plantation (spacing, age, composition of species), the soil and the management performed by farmers, in two reforestations with native species, established under the Taungya agroforestry system. We tested the hypothesis that the differences in management will be more important to explain the final results (accumulated biomass) than the other factors.

\section{Material and methods}

Study area - The study area was the area of Legal Reserve of Santa Zelia Settlement, at the city of Teodoro Sampaio, São Paulo, southwest of Brazil $\left(22^{\circ} 21^{\prime} \mathrm{S}\right.$ and $\left.52^{\circ} 25^{\prime} \mathrm{W}\right)$, in the region known as Pontal do Paranapanema. According to the Board of the Pontal do Paranapanema Hydrographic Basin (CBHPP 2008), the region is characterized by the Köppen's Cwa climate type (Subtropical with dry winters), with annual average temperatures lower than $22{ }^{\circ} \mathrm{C}$, and annual average precipitation ranging from 1200 to $1400 \mathrm{~mm}$.

The soils are originated from Bauru Group sandstone, with Red Dystrophic latosols predominant in the study area (CBHPP 2008). The relief has predominance of wide, small to mid-sized hills and long crests, occasional mounts and alluvial plains (CBHPP 2008). The original vegetation is highly fragmented, with predominance of remnants of Semidecidual Seasonal Atlantic Forest and Cerrado (CBHPP 2008).

The two reforestations were planted in degraded pastures designed to form the Legal Reserve of the settlement using Taungya system, with the engagement of the local resident families. In those reforestations the trees did not represent a direct economic component, having just an environmental role of restoring native forests, thus being a temporary agroforestry consortium (Rodrigues et al. 2007). Four stands of four farmer families in each reforestation 
area were studied, and the different practices employed by farmers (weed control, tree seedlings care, crop management etc) were recorded and considered as different forms of management.

The aboveground biomasses were compared among farmer stands and between areas (reforestations of different ages). The reforestations were called R1 and R2, and their method of implantation and the forms of management used by the farmer families were described below.

History of implantation - In both reforestations, the seedlings were obtained at the nursery of the São Paulo State Energy Company (CESP) located at the city of Primavera, São Paulo State. The composition of the seedling lots depended on the availability of the nursery, and the plantation was performed through random distribution, while avoiding seedlings of the same species to be neighbors. The crop seeds and other agricultural inputs to the crops were acquired by the farmer families themselves.

The R1 reforestation was implemented in January of 2004 in 12 hectares, which were divided into six families (stands) to the development of AFSs. Soil preparation was performed using heavy plow followed by leveling plow. The spacing used for native species seedlings plantation was of $2 \mathrm{~m}$ (between seedlings aligned) $\times 4 \mathrm{~m}$ (between the lines).

R2 reforestation was implemented in January 2006 in 27.5 hectares, divided among 11 families (one stand each) to the development of AFSs. Soil preparation was performed the same way as in R1, but with the addition of basaltic rock powder $\left(2 \mathrm{Mg} \cdot \mathrm{ha}^{-1}\right)$. The spacing used at the natives species seedlings plantation also differed, being of $2 \mathrm{~m}$ (between seedlings aligned) $\times 3 \mathrm{~m}$ (between the lines). No $\mathrm{pH}$ correctives or fertilizers were applied in any of the reforestations other than the basaltic rock powder (figure 1).

Agroforestry management - In the context of this work we consider, as part of the management performed by the families in the stands, the choice of the planted crop, the space and time sequences in which they were planted, the conduction and harvesting of these agricultural species, as well as the control of invasive grass species.

The accidental entrance of cattle in both reforestations happened many times, causing injuries like the breaking of trees branches and stems, aside from the trampling on the crop. Despite the difficulty to quantify the direct effect of these injuries to

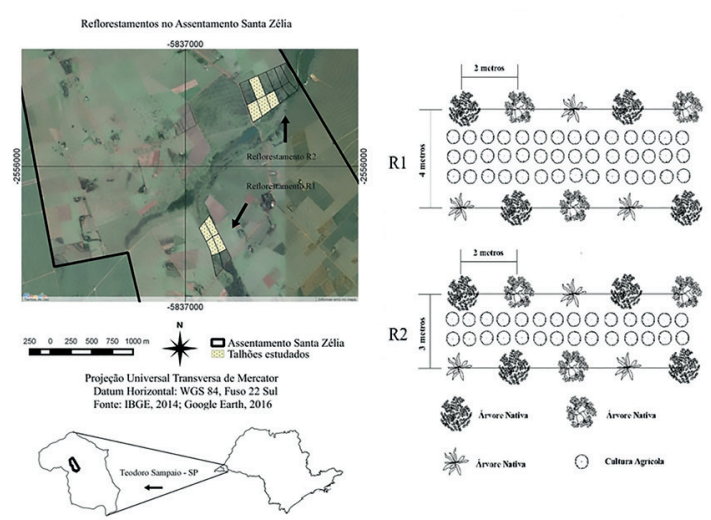

Figure 1. Location of the study areas in Santa Zélia Settlement, in Teodoro Sampaio municipality, São Paulo State, Brazil (left) and scheme of implementation of the reforestation by means of Taungya agroforestry system (right).

the development of planted trees and to the crop productivity, these events influenced on farmers willingness to invest in the project and consequently in the time of their permanence in the stands.

Four stands in each reforestation were selected for the study, named with the name of the chief of each family (table 1). At the $\mathrm{R} 1$ reforestation the farmers managed the stands for different periods, indicated between brackets after the name. At the R2 reforestation, all 12 farmers remained for 12 months in the stands.

Maintenance operations (weed control, especially invasive grass species) were performed in R1 and R2, after the exit of all farmers from their stands, from the beginning of 2007 until the end of 2009. During this period a brushcutter attached to a tractor was used between the tree lines, two times in R1 and three times in R2. In both reforestations post-emergent herbicide was applied once.

Aboveground biomass estimation - The data collection was performed in January and February of 2010. The sampling was performed in circular plots with $5.64 \mathrm{~m}$ of radius (100 $\mathrm{m}^{2}$ per plot; Winrock 2000). The distribution of plots in the field was systematic, keeping a distance of $25 \mathrm{~m}$ from the edges of the stands and between plots. Stands in R1 and R2 had 2 and 2.5 hectares respectively. Thus, in R1 was possible to place eight plots in each stand and in R2 10 plots per stand, adding up to 72 sampled plots.

In each plot, the geographic coordinates of the center were registered with GPS. Only the arboreal individuals with Circumference at Breast Height $(\mathrm{CBH})$ higher or equal to five centimeters were 
Table 1. Agroforestry management in two reforestation areas with six (R1) and four (R2) years of age in the Santa Zélia Settlement in Teodoro Sampaio, São Paulo State, Brazil.

$$
\text { R1 (2004) }
$$

Cidinho (18 months) - Planted Castor beans together with maize and, after harvest, planted cassavas.

Betão (6 months) - Planted maize. After the harvest Talhão 2 followed with weed control in the reforestation, but give up with further crops.

Talhão 3

Adão (12 meses) - Planted cassavas together with maize.

Talhão 4
Cícero (36 months) - Planted cassavas once.
R2 (2006)

Zulmira - Planted maize. After the harvest planted common beans.

Afonso - Planted maize. After the harvest planted common beans.

Pacheco - Planted maize, common beans, pumpkins, okra and maxixe, in random blocks.

Zé Buriti - Planted maize. After the harvest planted common beans. measured, including forked stems. $\mathrm{CBH}$ of each individual was measured at $1.3 \mathrm{~m}$ from the ground with a measuring tape and tree species was recorded. From the $\mathrm{CBH}$ it was obtained the Diameter at Breast Height (DBH), considering that one unit of circumference is equal 3,1416 $(\pi)$ diameter units. $(\mathrm{D}=\mathrm{C} / \pi)$. For forked trees, it was calculated the quadratic diameter (MacDicken et al. 1991):

$(\mathrm{Dq})=\sqrt{\left(D 1^{2}+D 2^{2}+D 3^{2}+\ldots D n^{2}\right)}$

Where $\mathrm{Dq}$ is the quadratic diameter of forked trees $(\mathrm{cm})$ and $\mathrm{D}$ the diameter of each tree stem (in $\mathrm{cm}$ ).

To the aboveground biomass calculation, it was used the generic equation developed by Brown (1997):

$\mathrm{B}=\exp [-1.996+2,32 * \operatorname{Ln}(D B H)]$

Where $\mathrm{B}$ is the aboveground biomass of each tree (in $\mathrm{kg}$ ) and DBH the Diameter at Breast Height (cm). Species-specific equations such as that provided by Jardim (2006) and Miranda et al. (2011) could not be used because of the range of stem diameter recorded in $\mathrm{R} 1$ and $\mathrm{R} 2(70 \%$ of trees with $\mathrm{DAP}<10 \mathrm{~cm})$ were found to be out of the range of available equations. This way, the equation of Brown was chosen because it allows the comparison between the reforestations studied here and between these reforestations and other similar sites reported in the literature (Melo \& Durigan 2006; IPEF non-published data, Bufo 2008). Aboveground biomass figures for each tree in each plot were added up in kilograms $(\mathrm{kg})$ and transformed in megagrams ( $\mathrm{Mg}$, equivalent to $1000 \mathrm{~kg}$ or one ton). Later, they were divided by the area of the plots and multiplied by 10.000 to obtain the figures in $\mathrm{Mg}^{-h^{-1}}$.
Soil samples $(0-20 \mathrm{~cm}$ depth) were collected with a manual auger in all stands at the time of tree measuring, to compare the levels of soil fertility between reforestation areas and stands. Three simple samples in each plot were collected and mixed up to form a composite sample. Approximately $0.5 \mathrm{~kg}$ of composite samples were separated for routine chemical analysis - including concentrations of Phosphorus (P), Potassium (K), Magnesium (Mg), Calcium (Ca), Aluminum (Al) and $\mathrm{pH}$, and also Sum of Bases (SB), Cation Exchange Capacity (T), Saturation by Bases (V) and Saturation by Aluminum (SAI) according to Pavan et al. (1992). All analysis was made by the Laboratory of Soil Analysis of the Agronomic Institute of Paraná at Londrina (IAPAR).

Data analysis The biomass data were transformed in logarithm, adjusting to a normal distribution, verified by Shapiro-Wilk test. The variance homogeneity was verified by Levene test (Zar 1998). Aboveground biomass comparisons between stands were made through analysis of factorial variance (using stand age and management as factors) and Tukey and Tukey-Kramer tests a posteriori, considering the differences to be significative when $p$ was equal or smaller than 0.05 . The soil analysis variables were also compared using Anova followed by Tukey test. Regression analyses were performed in order to test the effect of soil features upon biomass. A Principal Component Analysis (PCA) was performed in order to synthesize the information contained in the abundance distribution of species in the stands. The first four components of PCA were used in a regression analysis 
taking biomass as dependent variable, aiming to test the influence of species composition on biomass.

\section{Results}

A total of 599 trees of 50 species were sampled and identified; 222 trees of 30 species were in R1 and 377 trees of 40 species were in R2 (table 2). The average biomass at R1 stands was $17.43 \mathrm{Mg} \mathrm{ha}^{-1}$, varying from 8.31 to $23.97 \mathrm{Mg} \mathrm{ha}^{-1}$. Significant differences were found only between the extremes (Adão and Betão, figure 2; Tukey test, $\mathrm{p}=0.034$ ). The average stand biomass at R2 was $20.98 \mathrm{Mg} \mathrm{ha}^{-1}$ and, like at R1, there was a significant difference (Tukey, $\mathrm{p}=0.029$, figure 2 ) only between the extremes Afonso (13.75 $\mathrm{Mg} \mathrm{ha}^{-1}$ ) and Pacheco (29.89 $\mathrm{Mg} \mathrm{ha}^{-1}$ ). There was no significant difference between 2004 stands (R1) and 2006 stands (R2). The tree density did not explain biomass (regression, $\mathrm{r}^{2}=0.137, \mathrm{p}=0.197$ ). The floristic composition varied little between stands and the factors extracted from PCA also did not explain biomass variation (multiple regression, $\mathrm{r}^{2}$ adjusted $=0.09, \mathrm{p}=0.47$ ).

The soil analysis results are presented on table 3 , with average figures for each stand. As it were

Table 2. Number of trees recorded per species in two reforestation areas with six (R1) and four (R2) years of age in the Santa Zélia Settlement in Teodoro Sampaio, SP, Brazil. The names in the columns indicate different families of farmers with different management practices.

\begin{tabular}{|c|c|c|c|c|c|c|c|c|}
\hline \multirow[b]{2}{*}{ Species } & \multicolumn{4}{|c|}{ Reforestation R1 } & \multicolumn{4}{|c|}{ Reforestation R2 } \\
\hline & Cidinho & Betão & Adão & Cícero & Zulmira & Afonso & Pacheco & $\begin{array}{c}\text { Zé } \\
\text { Buriti }\end{array}$ \\
\hline Acacia spp. & & & 4 & 3 & & & & \\
\hline Aegiphila sellowiana Cham. & & & 1 & & & & & \\
\hline Allophylus guaraniticus (A. St.-Hil.) Radlk. & & & & & & & & 1 \\
\hline Anadenanthera macrocarpa (Benth.) Brenan & 2 & 1 & 7 & 10 & 4 & 4 & 2 & 1 \\
\hline Apuleia leiocarpa (Vogel) J.F. Macbr. & & & & & & & 1 & 3 \\
\hline Cariniana legalis (Mart.) Kuntze & & & & & & 1 & & \\
\hline Casearia gossypiosperma Briq. & & & & & & & & 1 \\
\hline Cecropia pachystachya Trécul & 1 & & & & 2 & 1 & 3 & 1 \\
\hline Ceiba speciosa (A.St.-Hil.) Ravenn & 3 & & & 1 & & & 1 & 1 \\
\hline Cedrela fissilis Vell. & & & & & & 1 & 1 & \\
\hline Citharexylum myrianthum Cham. & & & & & 1 & & 2 & \\
\hline Cordia americana (L.) Gottschling \& J.S.Mill. & 1 & & & & & & & \\
\hline Cordia superba Cham. & & & & & 3 & 2 & 2 & 2 \\
\hline Cordia trichotoma (Vell.) Arráb. ex Steud. & 3 & 1 & & 2 & & & & \\
\hline Croton floribundus Spreng. & 1 & 1 & 5 & 2 & 4 & 9 & 7 & 4 \\
\hline Croton urucurana Baill. & 1 & 6 & 8 & 6 & 16 & 9 & 23 & 18 \\
\hline Enterolobium contortisiliquum (Vell.) Morong & 1 & 1 & & 2 & & 2 & & 1 \\
\hline Erythrina verna Vell. & & & & & 1 & & & \\
\hline Eugenia myrcianthes Nied. & 1 & & & & & & & \\
\hline Eugenia uniflora L. & 1 & & & 1 & & & & \\
\hline Ficus gomelleira Kunth & 1 & 1 & & 1 & & 2 & 5 & \\
\hline Ficus insipida Willd. & & & & & & 1 & & 2 \\
\hline Gallesia integrifolia (Spreng.) Harms & & & & & & & 1 & \\
\hline Genipa americana $\mathrm{L}$. & & & & & & 1 & & 1 \\
\hline Guazuma ulmifolia Lam. & 8 & 4 & 8 & 19 & 34 & 26 & 38 & 26 \\
\hline Handroanthus heptaphyllus (Vell.) Mattos & & & & & 2 & 3 & 3 & 2 \\
\hline
\end{tabular}


Table 1 (continuation)

\begin{tabular}{|c|c|c|c|c|c|c|c|c|}
\hline \multirow[b]{2}{*}{ Species } & \multicolumn{4}{|c|}{ Reforestation R1 } & \multicolumn{4}{|c|}{ Reforestation R2 } \\
\hline & Cidinho & Betão & Adão & Cícero & Zulmira & Afonso & Pacheco & $\begin{array}{c}\text { Zé } \\
\text { Buriti }\end{array}$ \\
\hline Handroanthus impetiginosus (Mart. ex DC.) MattosStandl. & & & & & & & & 1 \\
\hline Handroanthus umbellatus (Sond.) Mattos & & & & & & & 1 & 1 \\
\hline Hymenaea courbaril L. & & & & & & 1 & & \\
\hline Inga edulis Mart. & & & & 2 & & 3 & 1 & \\
\hline Inga laurina (Sw.) Willd. & 1 & 1 & & 1 & 3 & & 4 & 2 \\
\hline Jacaranda cuspidifolia Mart. & & & & 1 & 1 & & & \\
\hline Luehea divaricata Mart. \& Zucc. & & 6 & & & & & 1 & \\
\hline Mabea fistulifera Mart. & & & 1 & & 2 & & 1 & \\
\hline Machaerium aculeatum Raddi & 1 & & & & & & & \\
\hline Maclura tinctoria (L.) D.Don ex Steud. & 2 & & & & 1 & 2 & & \\
\hline Margaritaria nobilis L.f. & & & & & 1 & 2 & 2 & 1 \\
\hline Mimosa caesalpiniifolia Benth. & 2 & & & & & & & \\
\hline Myracrodruon urundeuva Allemão & & & 2 & 1 & 1 & & 1 & \\
\hline Parapiptadenia rigida (Benth.) Brenan & 4 & 5 & & 6 & & 1 & & \\
\hline Peltophorum dubium (Spreng.) Taub. & 5 & 18 & 2 & 6 & 8 & 6 & 4 & 2 \\
\hline Psidium guajava $\mathrm{L}$. & & & & & & 1 & 1 & 2 \\
\hline Pterogyne nitens Tul. & & & & 1 & & & & \\
\hline Schinus terebinthifolius Raddi & 3 & & & & 7 & 4 & 4 & 7 \\
\hline Senegalia polyphylla (DC.) Britton \& Rose & 1 & & 12 & 10 & & 1 & 1 & \\
\hline Solanum paniculatum $\mathrm{L}$. & & 1 & & & & & & \\
\hline Tapirira guianensis Aubl. & & & & & & 2 & & \\
\hline Trema micrantha (L.) Blume & 6 & & & 2 & 2 & 3 & 1 & \\
\hline Triplaris americana $\mathrm{L}$. & & & & & 2 & & & 1 \\
\hline Zeyheria tuberculosa (Vell.) Bureau ex Verl. & & & & & & 2 & & \\
\hline Total & 49 & 46 & 50 & 77 & 95 & 90 & 111 & 81 \\
\hline
\end{tabular}

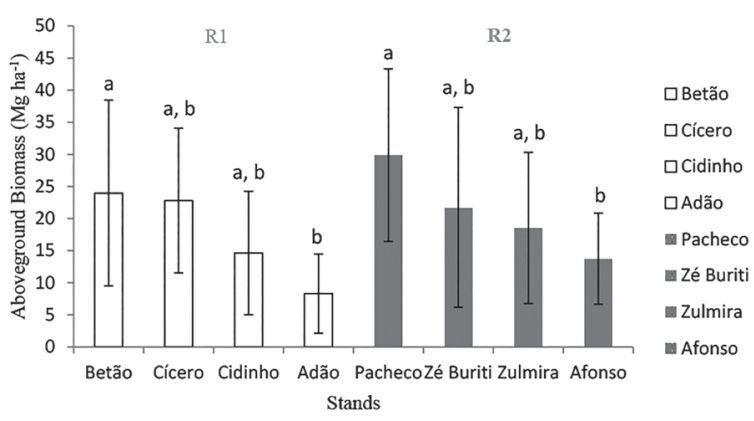

Figure 2. Mean and standard deviation of the estimates of aboveground biomass $\left(\mathrm{Mg} \mathrm{ha}^{-1}\right)$ in two reforestation areas with six (R1-white) and four (R2-grey) years of age in the Santa Zélia Settlement in Teodoro Sampaio, SP, Brazil. The names in the $\mathrm{X}$ axis indicate different families of farmers with different management practices. The letters above the bars, when different from the same age plots, indicate significant differences $(\mathrm{p}<0.05)$ between the means analyzed with Tukey test $(\mathrm{p}=0.034$ for $\mathrm{R} 1$ and $\mathrm{p}=0.029$ to $\mathrm{R} 2$ ).

subdivisions of the same plot, there were not any important differences between stands of the same age. At R2 stands, higher figures of P, SB, T, V and smaller SAI were found when compared to R1, what probably occurred because of the application of basaltic rock powder when preparing R2 soil. Both R1 and R2 showed low fertility, common feature of the regional soils. None of the soil variables could explain biomass variation (regression, $\mathrm{r}^{2}$ varying from 0.03 for $\mathrm{pH}$ to 0.003 for $\mathrm{P}$ and $p$ values ranging from 0.095 for $\mathrm{pH}$ to 0.82 for $\mathrm{SB}$ ).

\section{Discussion}

In general, the estimated figures for aboveground biomass are smaller, but within the same magnitude order, when compared to data reported for other reforestations in the same region like, for example, Melo \& Durigan (2006) (54.8 $\mathrm{Mg} \mathrm{ha}^{-1}$ after five years of tree plantation and $62.2 \mathrm{Mg} \mathrm{ha}^{-1}$ after six years). At the region of Promissão, SP, figures of $30.9 \mathrm{Mg} \mathrm{ha}^{-1}$ after four years and of $41.7 \mathrm{Mg} \mathrm{ha}^{-1}$ after five years were estimated (IPEF, unpublished data). However, differences in biomass cannot be attributed only to soil and climate of each region, but also to the fact that these reforestations were implanted and conducted under different project design, without using agroforestry techniques. 
Table 3. Soil analysis (0-20 cm depth) in two reforestation areas with six (R1) and four (R2) years of age in the Santa Zélia Settlement in Teodoro Sampaio, SP, Brazil. Same letters indicate no difference after Tukey test; comparisons restricted to columns.

\begin{tabular}{|c|c|c|c|c|c|c|c|c|c|c|c|c|c|}
\hline Area & Stands & $\begin{array}{c}\mathrm{P} \\
\mathrm{mg} / \mathrm{dm}^{3}\end{array}$ & $\begin{array}{c}\mathrm{MO} \\
\mathrm{dg} / \mathrm{Kg}\end{array}$ & $\begin{array}{c}\mathrm{PH} \\
\mathrm{CaCl}_{2}\end{array}$ & \multicolumn{7}{|c|}{ cmolc/dm ${ }^{3}$} & $\begin{array}{l}\mathrm{V} \\
\%\end{array}$ & $\begin{array}{c}\text { SAI } \\
\%\end{array}$ \\
\hline \multirow{4}{*}{ R1 } & Cidinho & $2,81^{\mathrm{b}}$ & $6,7^{b}$ & $4,63^{b}$ & $0,07^{b}$ & $3,00^{\mathrm{b}}$ & $0,29^{\mathrm{a}}$ & $0,28^{c}$ & $0,11^{\mathrm{bc}}$ & $0,63^{\mathrm{a}}$ & $3,63^{\mathrm{ab}}$ & $23.81^{\mathrm{ab}}$ & $10,15^{\mathrm{ab}}$ \\
\hline & Betão & $1,95^{\mathrm{b}}$ & $6,3^{b}$ & $4,46^{\mathrm{b}}$ & $0,15^{\mathrm{a}}$ & $3,24^{\mathrm{ab}}$ & $0,26^{\mathrm{a}}$ & $0,32^{\mathrm{bc}}$ & $0,16^{\mathrm{a}}$ & $0,74^{\mathrm{a}}$ & $3,98^{\mathrm{ab}}$ & $18,56^{\mathrm{ab}}$ & $17,49^{\mathrm{a}}$ \\
\hline & Adão & $1,88^{\mathrm{b}}$ & $7,18^{\mathrm{ab}}$ & $4,81^{\mathrm{ab}}$ & $0,05^{\mathrm{b}}$ & $3,12^{\mathrm{ab}}$ & $0,46^{\mathrm{a}}$ & $0,44^{\mathrm{ab}}$ & $0,21^{\mathrm{a}}$ & $1,11^{\mathrm{a}}$ & $4,23^{\mathrm{ab}}$ & $26,24^{\mathrm{a}}$ & $4,81^{\mathrm{ab}}$ \\
\hline & Cícero & $2,59^{b}$ & $4,22^{\mathrm{c}}$ & $4,61^{\mathrm{b}}$ & $0,05^{\mathrm{b}}$ & $2,68^{\mathrm{b}}$ & $0,24^{\mathrm{a}}$ & $0,18^{\mathrm{c}}$ & $0,07^{\mathrm{c}}$ & $0,49^{\mathrm{a}}$ & $3,17^{\mathrm{b}}$ & $15,45^{\mathrm{b}}$ & $11,26^{\mathrm{a}}$ \\
\hline \multirow{4}{*}{$\mathrm{R} 2$} & Zulmira & $5,16^{\mathrm{a}}$ & $8.56^{\mathrm{a}}$ & $4,58^{\mathrm{b}}$ & $0,07^{\mathrm{b}}$ & $3,35^{\mathrm{a}}$ & $0,69^{\mathrm{a}}$ & $0,51^{\mathrm{a}}$ & $0,15^{\mathrm{a}}$ & $1,35^{\mathrm{a}}$ & $4,70^{\mathrm{a}}$ & $28,72^{\mathrm{a}}$ & $4,73^{\mathrm{ab}}$ \\
\hline & Afonso & $3,18^{\mathrm{b}}$ & $7,53^{\mathrm{ab}}$ & $4,53^{b}$ & $0,08^{b}$ & $3,30^{\mathrm{ab}}$ & $0,47^{\mathrm{a}}$ & $0,43^{\mathrm{a}}$ & $0,11^{\mathrm{c}}$ & $1,01^{\mathrm{a}}$ & $4,31^{\mathrm{a}}$ & $23,43^{\mathrm{ab}}$ & $7,33^{\mathrm{ab}}$ \\
\hline & Pacheco & $4,84^{\mathrm{a}}$ & $7,27^{\mathrm{ab}}$ & $4,64^{\mathrm{b}}$ & $0,08^{b}$ & $3,43^{\mathrm{a}}$ & $0,52^{\mathrm{a}}$ & $0,49^{\mathrm{a}}$ & $0,16^{\mathrm{ab}}$ & $1,17^{\mathrm{a}}$ & $4,60^{\mathrm{a}}$ & $25,43^{\mathrm{ab}}$ & $7,01^{\mathrm{ab}}$ \\
\hline & $\begin{array}{c}\text { Zé } \\
\text { Buriti }\end{array}$ & $4,22^{\mathrm{ab}}$ & $6,47^{\mathrm{b}}$ & $4,89^{\mathrm{a}}$ & $0,02^{\mathrm{b}}$ & $3,20^{\mathrm{ab}}$ & $0,66^{\mathrm{a}}$ & $0,52^{\mathrm{a}}$ & $0,11^{\mathrm{c}}$ & $1,29^{\mathrm{a}}$ & $4,49^{\mathrm{a}}$ & $28,73^{\mathrm{a}}$ & $1,83^{\mathrm{b}}$ \\
\hline
\end{tabular}

These results reinforce indications found in literature that biomass accumulation in AFSs is highly variable, depending not just on the local primary productivity, which depends on factors like soil and climate, but also on the selection of species that were used and on the stand management practices (Nair et al. 2009). The agroforestry management performed at the stands in the present study was also highly variable, mainly because of the different characteristics of life and work of the farmer families. Probably the most important management feature to influence the results was the duration of the crop cycle for each family, and consequently the time in which crop management, specially the control of invasive species, were kept by farmers in the different stands. This management variation has the biggest potential of explanation of variations in the aboveground biomass accumulation, once there were not differences between stands of different ages and also there was not any correlation with soil characteristics or with species composition of the reforestations, not even with tree density in the stands. The significant differences between extremes in both reforestations probably were the consequence of different intensities in the control of invading grass species, of density of crop planting and also of the injuries caused by cattle in all agroforestry stands. The lack of these information, as well as the absence of true replicates for all types of management make impossible to verify the individual effect of different aspects of agroforestry management practices on the results.

For example, in $\mathrm{R} 1$ it is possible to notice that biomass in Betão was slightly bigger than in Cícero (although the difference is not significative) even with
$40 \%$ less of sampled trees. This may have happened because of the duration of cassava cycle at the stand of this farmer, increasing the time of competition between trees and crop. Cidinho obtained $61 \%$ of the biomass of Betão, with practically the same amount of sampled trees. In this case, the simultaneous cropping of castor beans and corn at the beginning of management, in the stand of Cidinho, may have caused a high competition with trees. It is also possible to notice that in R 2 Afonso obtained $63 \%$ of the biomass of Zé Buriti, with 10\% more sampled trees. In this case, the intensity and frequency on the control of invasive grass species may have caused this difference, once the time that the families remained in the stands was similar. However, as highlighted above, these are speculations, once it is not possible to test each of these propositions because of the lack of replicates of management types and also there were not significant differences for part of the comparisons.

Schlönvoigt \& Beer (2001) suggest that the growth rate of arboreal species is what should guide the choice of crop species and spacing, in order to avoid problems due to competition for resources between trees and crop plants which can lead to delayed tree development. On the other side, even in reforestations designed only for environmental goals, it can be acceptable to use larger spacing, or even to tolerate a certain level of loss in tree development if that allows higher social benefits, without affecting the final goal.

The use of a general equation for biomass estimation can be acceptable to estimate growing rates, because repeated measures for several years at the same place did not involve great changes in 
the composition of species and local specificities (Ketterrings et al 2001). The same way, as the reforestations were made with a reasonably similar species composition, this kind of distortion is not a concern for data discussion, even thought it limits the comparisons of these results with others in the future.

Therefore, the results of this study suggest that, in native species reforestations done by means of Taungya agroforestry system, aboveground biomass accumulation can be chiefly influenced by management characteristics, once the observed variations showed to be independent from age (within the time interval considered), tree density and species composition and soil fertility. With the data presently available, it is not possible to decompose the variance associated to each management component, such as the type and the duration of the crop. Formal experiments with management type replicates are necessary to elucidate those questions. Even though higher biomass accumulation has been reported on literature in other reforestations in Seasonal Atlantic Forest domain, it is considered that the figures estimated in this study are in the same magnitude order and but referring to reforestations implanted through agroforestry technique, that present obvious socioeconomic benefits, at least softening the costs of ecological restoration.

\section{Literature cited}

Brown, S. 1997. Estimating biomass and biomass changing of tropical forests: a primer. FAO Forestry Paper 134: 1-55.

Bufo, L.V.B. 2008. Restauração florestal e estoque de carbono em modelos de implantação de mudas sob diferentes combinações de espécies e espaçamentos. Dissertação de Mestrado, Universidade de São Paulo, Piracicaba.

Burger, D.M. \& Dellitti, W. 1999. Fitomassa epígea da mata ciliar do rio Mogi-Guaçú, Itapira SP. Revista Brasileira de Botânica 22: 429-435.

Chamshama, S.A.O., Monela, G.C., Sekiete, K.E.A. \& Persson, A. 1992. Suitability of the Taungya system at North Kilimanjaro forest plantation, Tanzania. Agroforestry Systems 17: 1-11.

CBHPP. 2008. Características Gerais da UGRHI do Pontal do Paranapanema. Available in http://paranapanema. org/ugrh/comites/sp/cbhpp/caracterizacao (access in 21-IX-2016).

Froufe, L.C.M., Rachwal, M.F.G. \& Seoane, C.E.S. 2011. Potencial de sistemas agroflorestais multiestrata para sequestro de carbono em áreas de ocorrência de Floresta Atlântica. Pesquisa Florestal Brasileira 31: 143-154.
Higuchi, N. 1994. Utilização e Manejo dos Recursos Madeireiros das Florestas Tropicais Úmidas. Acta Amazonica 24: 275-288.

IPEF. 2006. Instituto de Pesquisas e Estudos Florestais. Análise ecológica, dendrométrica e do uso potencial de espécies arbóreas nativas em plantios consorciados visando o sequestro de carbono. Instituto de Pesquisas e Estudos Florestais, Piracicaba.

Jardim, P.S. 2006. Acúmulo de biomassa e sequestro de carbono em reflorestamentos com espécies nativas. Dissertação de Mestrado, Universidade Estadual de Londrina, Londrina.

Jose, S. 2009. Agroforestry for ecosystem services and environmental benefits: an overview. Agroforestry Systems 76: 1-10.

Ketterings, Q.M., Coe, R., Noordwijk, M.V., Ambagau, Y.\& Palm, C.A. 2001. Reducing uncertainty in the use of allometric biomass equations for predicting aboveground tree biomass in mixed secondary forest. Forest Ecology and Management 146: 199-209.

MacDicken, K.G., Wolf, G.V. \& Briscoe, C.B. 1991. Standard research methods for multipurpose tree and shrubs. Winrock International Institute for Agricultural Development/ICRAF, Arlington.

Melo, A.C.G. \& Durigan, G. 2006. Fixação de carbono em reflorestamentos de restauração e em matas ciliares nativas no Vale do Paranapanema, SP, Brasil. Scientia Forestalis 71: 149-154.

Miranda, D.L.C., Melo, A.C.G. \& Sanquetta, C.R. 2011. Equações alométricas para estimativa de biomassa e carbono em árvores de reflorestamentos de restauração. Revista Árvore 35: 679-689.

Nair, P.K.R., Kumar, B.M. \& Nair, V.D. 2009. Agroforestry as a strategy for carbon sequestration. Journal of Plant Nutrition and Soil Science 172: 10-23.

Nair. P.K.R. 2012. Carbon sequestration studies in agroforestry systems: a reality-check. Agroforestry Systems 86: 243-253.

Pavan, M.A., Bloch, M.M.F., Zempulski, H.C., Miyazawa, M. \& Zocoler, D.C. 1992. Manual de análise química de solo e controle de qualidade. Instituto Agronômico do Paraná, Londrina.

Rodrigues, E.R., Cullen Jr., L., Beltrame, T.P. \& Moscogliato, A.V. 2007. Avaliação econômica de sistemas agroflorestais implantados para a recuperação de reserva legal no Pontal do Paranapanema, São Paulo. Revista Árvore 31: 941-948.

Rodrigues, E.R., Cullen Jr., L., Moscogliato, A.V. \& Beltrame, T.P. 2008. O uso do sistema agroflorestal Taungya na restauração de reservas legais: indicadores econômicos. Revista Floresta 38: 517-525.

Sanquetta, C.R. \& Balbinot, R. 2004. Metodologias para determinação de biomassa florestal. In: C.R. Sanquetta, R. Balbinot, M.A.B. Ziliotto (orgs.). Fixação de carbono: atualidades, projetos e pesquisas. UFPR/ ECOPLAN, Curitiba, pp. 77-93. 
Schlonvoigt, A. \& Beer, J. 2001. Initial growth of pioneer timber tree species in a Taungya system in the humid lowlands of Costa Rica. Agroforestry Systems 51:97-108.

Silveira, P., Koehler, H.S., Sanquetta, C.R. \& Arce, J.E. 2008. O estado da arte na estimativa de biomassa e carbono em formações florestais. Revista Floresta 38: 185-206.

Somogyi, Z., Cienciala, E., Makipaa, R., Muukkonen, P., Lehtonen, A. \& Weiss, P. 2007. Indirect methods of large-scale forest biomass estimation. European Journal of Forest Research 126: 197-207.
Taiz, L. \& Zeiger, E. 2002. Plant Physiology. 3 ed. Sinauer Associates, Sunderland.

Vieira, D.L.M., Holl, K.D. \& Peneireiro, F.M. 2009. Agrosuccessional restoration as a strategy to facilitate tropical forest recovery. Restoration Ecology 17: 451-459.

Winrock. 2000. Elementos técnicos para inventários de carbono em uso del suelo. Winrock International Institute for Agricultural Development, Arlington.

Zar, J.H. 1998. Biostatistical analysis. 3 ed. Prentice Hall, New Jersey. 